\title{
The Influence Of Organizational Learning On Improving The Accreditation Of Public Health Kubutambahan I And Public Health Sawan I In Buleleng District - Bali
}

Gede Ivan Kresnayana
Magister of Public Health Program of
Institut Ilmu Kesehatan STRADA
Indonesia
Email:
publikasistrada@gmail.com

Received : October 12, 2019

Accepted : February 13, 2020

Published : May 12, 2020

\begin{abstract}
The Accreditation Process is still a frightening specter at every Puskesmas. Accreditation is a benchmark for extrenal quality assurance at each puskesmas through Organizational Learning efforts. The study aims to analyze the Effect of Organizational Learning on Improving Accreditation of Kubutambah I Health Center and Sawan I Health Center in Buleleng Regency - Bali. The method used is a mix method, observational research type with cross-sectional approach. The population in this study involved 2 Community Health Centers namely Kubutambah 1 and Sawan 1 with 100 respondents with a purposive sampling technique. The research instrument used a questionnaire with closed questions that had a valid and reliable test of 0.6. Data analysis used in the study was a logistic regression statistical test with $\alpha$ 0.05. Analysis of Kubutambahn I Public Health Center and Sawan I Public Health Center in Buleleng Regency showed that out of 100 respondents or information from 2 health centers there were Organizational Learning in the good category of $62 \%$ and $38 \%$ not good. good category $98 \%$ and not good as much as $2 \%$, the relationship between Organizational Learning and the performance of accreditation of puskesmas in Buleleng Regency with a p-value of 0.047 , which means it is smaller than $\alpha 0.05$ so there is an influence of Learning Organization on accreditation. There is the effect of Organizational Learning on the performance of accreditation at Kubutambahn I Puskesmas and Sawan 1 Puskesmas in Buleleng Regency
\end{abstract}

Keywords: Accreditation, Public Health Centre, Learning Organization 


\section{INTRODUCTION}

Public health accreditation has been in force since the issuance of Minister of Health Regulation (Permenkes) No. 462015 on Public health Accreditation, Primary Clinics, Independent Doctors Practices and Independent Dentists Practices. According to Permenkes Number 46 of 2015, accreditation is an acknowledgment given by an independent accreditation provider established by the Minister after meeting accreditation standards. The main purpose of Public health accreditation is to foster quality and performance improvement through continuous improvement of the management system, quality management system and service delivery system and programs, as well as the application of risk management, and not just an assessment to get an accreditation certificate.

Policy on Public health accreditation is also regulated in Minister of Health Regulation No. 71 of 2013 concerning Health Services on National Health Insurance. In Article 6 of the requirements that must be met in order to work with BPJS Health paragraph 2, it is stated that all First Level Health Facilities (FKTP) must be accredited. Article 41 paragraph 2 states that FKTP is given until 2019 to have accreditation status in accordance with established standards. One of the objectives of the Buleleng District Health Office Strategic Plan is the realization of quality and professional health services. The target of coverage of basic health facilities according to the standard or plenary accredited is $100 \%$ in 2019. All Puskesmas in Buleleng Regency have proceeded to prepare for the accreditation survey starting in 2015. Achieving the value of accreditation, both survey results and self-assessment by Puskesmas (self assessment) is a picture of the performance achievements of the accreditation process carried out by the Public health center.

\section{METHODS}

This research is a mix methods research, which is a step of research by combining two forms of approach in research, namely qualitative and quantitative. This research was conducted in two Public health in Buleleng Regency. The study was conducted from November 2019 to December 2019. The population studied in this study were 5 Public health in Buleleng Regency. The sampling technique in this study uses random sampling with a sample size of 2 Public health, with the dependent variable being the accreditation of the independent variable Public health Organizational Learning Capability and Dimensions of Learning Organization, which will be analyzed using bivariate data analysis using statistical tests chi square and multivariate analysis used using statistical tests namely logistic regression.

\section{RESULTS}

\section{Description of Research Sites}

Kubutambahan Health Center I was built in 1976 on the land owned by the Kubut auxiliary village of $1,540 \mathrm{~m} 2$ with ownership rights to use land with an area of $344.85 \mathrm{~m} 2$ of public health centre. The Kubutambah I Public health consists of 5 villages namely Kubutambah Village ,vidence Village, Bulian Village, Bengkala Village, and Depeha Village. The furthest distance from the village to the Public health is $10 \mathrm{~km}$, each village can be reached by 2 -wheeled or 4-wheeled vehicles.

\section{Data Analysis Description}

Table 1 Frequency distribution of characteristics of Respondents in Kubutambah 1 Health Center and Sawan 1 Health Center in 2019

\begin{tabular}{|c|c|c|c|}
\hline No & Education & Frecuency & Presentase \\
\hline 1 & SMA/Sederajat & 10 & $10 \%$ \\
\hline 2 & Diploma (D1) & 10 & $10 \%$ \\
\hline 3 & Diploma (D2) & 5 & $5 \%$ \\
\hline 4 & Diploma (D3) & 33 & $33 \%$ \\
\hline 5 & Diploma (D4) & 15 & $15 \%$ \\
\hline 6 & S1+Profesi & 15 & $15 \%$ \\
\hline 7 & S2 & 12 & $12 \%$ \\
\hline \multicolumn{2}{|c|}{ Total } & 100 & $100 \%$ \\
\hline
\end{tabular}

Sumber data: Data Primer (2019) 
The results of univariate analysis found that based on Table 1 the results of the study with respondents included the Head of the Puskesmas, the chairman and members of each Puskesmas accreditation working group (administrative management, UKM and UKP) who knew the condition of Organizational Learning at the Puskesmas, most were mostly Diploma III educated as many as 33 respondents (33\%). While the lowest number of diploma II educated was 5 people (5\%).

Table 2 results of evaluations on organizational learning in two Puskesmas including Kubutambah 1 Puskesmas and Sawan 1 Puskesmas 2019.

\begin{tabular}{|l|l|l|l|}
\hline $\begin{array}{l}\text { N } \\
\text { o }\end{array}$ & $\begin{array}{l}\text { Organizational } \\
\text { learning result }\end{array}$ & Frekuensi & Presentase \\
\hline 1 & Tidak Baik & 38 & $38 \%$ \\
\hline 2 & Baik & 62 & $62 \%$ \\
\hline Total & 100 & $100 \%$ \\
\hline
\end{tabular}

Sumber data: Data Primer (2019)

Based on the results of research with respondents including the Head of the Puskesmas, the chairperson and members from each Puskesmas accreditation working group (administration management, UKM and UKP) who knew the condition of Organizational Learning at the Puskesmas most of the most knowledgeable were 52 respondents (52\%). While the lowest number of people with less knowledge is 8 people (5\%).

Table 3 evaluation results on organizational learning in two Public health including Kubutambah 1 Public health and Sawan 1 Public health 2019.

\begin{tabular}{|l|l|l|l|}
\hline $\begin{array}{l}\text { N } \\
\text { o }\end{array}$ & $\begin{array}{l}\text { Organizational } \\
\text { learning result }\end{array}$ & Frekuensi & Presentase \\
\hline 1 & Tidak Baik & 38 & $38 \%$ \\
\hline 2 & Baik & 62 & $62 \%$ \\
\hline Total & 100 & $100 \%$ \\
\hline
\end{tabular}

Sumber data: Data Primer (2019)

Based on the results of table 5.3 that organizational learning that is applied to both puskesmas with the number of respondents or informants is 100 respondents stated that organizational learning is categorized as good as 62 respondents $(62 \%)$ and only a small portion of organizational learning in the category is not good as many as 38 respondents (38\%).

Table 4 results of evaluations on the achievement of accreditation in two Public health including Kubutambah 1 and Public health Sawan 1 Tahun 2019

\begin{tabular}{|l|l|l|l|}
\hline $\begin{array}{c}\text { N } \\
\text { o }\end{array}$ & $\begin{array}{c}\text { Hasil } \\
\text { pencapaian } \\
\text { akreditasi }\end{array}$ & $\begin{array}{c}\text { Frekuen } \\
\text { si }\end{array}$ & $\begin{array}{c}\text { Presentas } \\
\text { e }\end{array}$ \\
\hline 1 & Tidak Baik & 2 & $2 \%$ \\
\hline 2 & Baik & 98 & $98 \%$ \\
\hline Total & 100 & $100 \%$ \\
\hline
\end{tabular}

Sumber data: Data Primer (2019)

Based on the results of table 4 that the achievement of accreditation in both puskesmas obtained from the questionnaire analysis Organizational performance for Puskesmas accreditation achievement data seen from the results of Puskesmas accreditation self assessment in Buleleng Regency in 2019 with the number of respondents or informants was 100 respondents stated that accreditation achievements were categorized good as many as 98 respondents $(98 \%)$ and only a small proportion stated not good as many as 2 respondents (2\%). 
Table 5 Analysis of Bivariate Statistical Tests for the effect of organizational learning on the achievement of Public health accreditation in Buleleng Regency.

Count

Organisasi_learning * Pencapaian_akreditasi Crosstabulation

\begin{tabular}{|ll|r|r|r|}
\hline & & \multicolumn{2}{|c|}{ Pencapaian_akreditasi } & \multirow{2}{*}{ Total } \\
\cline { 3 - 4 } & & Tidak baik & \multicolumn{1}{c|}{ Baik } & \multicolumn{1}{c|}{ Taik } \\
Organisasi_learning & Tidak Baik & 2 & 32 & 34 \\
& Baik & 0 & 66 & 66 \\
Total & & 2 & 98 & 100 \\
\hline
\end{tabular}

Chi-Square Tests

\begin{tabular}{|c|c|c|c|c|c|}
\hline & Value & df & $\begin{array}{l}\text { Asymp. Sig. } \\
\text { (2-sided) }\end{array}$ & $\begin{array}{l}\text { Exact Sig. (2- } \\
\text { sided) }\end{array}$ & $\begin{array}{l}\text { Exact Sig. (1- } \\
\text { sided) }\end{array}$ \\
\hline Pearson Chi-Square & $3.962^{\mathrm{a}}$ & 1 & .047 & \multirow{6}{*}{.113} & \multirow{6}{*}{.113} \\
\hline Continuity Correction ${ }^{\mathrm{b}}$ & 1.529 & 1 & .216 & & \\
\hline Likelihood Ratio & 4.395 & 1 & 036 & & \\
\hline Fisher's Exact Test & & & & & \\
\hline Linear-by-Linear & 3.922 & 1 & .048 & & \\
\hline $\begin{array}{l}\text { Association } \\
\mathrm{N} \text { of Valid Cases }\end{array}$ & & & & & \\
\hline
\end{tabular}

a. 2 cells $(50.0 \%)$ have expected count less than 5. The minimum expected count is .68.

b. Computed only for a $2 \times 2$ table

Based on table 5 that there is a close relationship or between the effect of organizational learning on the achievement of puskesmas accreditation in Buleleng Regency. With a p-value of 0.047 which means less than $\alpha 0.05$, it is concluded that there is an influence of organizational learning on the achievement of Public health accreditation in Buleleng Regency in 2019.

\section{DISCUSSION}

\section{Analyzing Learning Organization Public health in Buleleng Regency}

Based on the results of data analysis and analysis by table 5.3 that organizational learning applied to both puskesmas with 100 respondents or informants stated that organizational learning was categorized as good as 62 respondents (62\%) and only a small portion of organizational learning was in the not good category as much as 38 respondents (38\%).

Based on data from the questionnaire that was answered either by the informant or the respondent on the Organizational Learning Capability dimension. Data from the questionnaire shows the value ranges from 80-98\% that Organizational Learning is concluded good or good because based on the number of respondents' answers are high. In addition to the dimensions of Organizational Learning Capability. Respondents have good grades on) Organizational Learning Process, including: (1) Knowledge acquisition. (2) Information distribution. (3) Information interpretation. (4) Organizatonal memory. The results of the respondents' analysis were also taken in a structured interview to find out Organizational Learning that this activity is always implemented by the head of the puskesmas in both apple events and routine meetings.

Based on theoretical foundations the Concept of Learning Organization has been linked to innovation and performance in organizations in several studies (Power \& Waddle, 2004; Watkins and Marsick 1993). The ability to change and carry out continuous improvement efforts to overcome the challenges of the environment, where organizations operate according to the ability of organizations to learn (Foley, 2003; Senge, 1990). Organizations that experience the learning process will be able to equal the development and improvement in the environment (competitors / competitors) in the direction of success.

Learning Organizations are needed to survive changes in the rapidly changing external environment. The inability of organizations to learn causes organizations to lose knowledge which will lead to repetitive patterns of mistakes, reduce productivity, and reduce performance. (Martins and Martins, 2011). The results of the correlation test between learning organizations and knowledge 
performance conducted at the Whiz Hotel in 2015 showed a significant relationship. Learning Organization has a role as supporting activities in implementing value chain as the main activity in increasing the effectiveness of research and learning conducted by organizations which ultimately brings success to innovation strategies. Research conducted by Nazari (2012) also shows that the Learning Organization dimension is positively and significantly correlated with the scale of organizational commitment.

The concept of Learning Organization or learning organization began to be introduced by Senge (1990) and until now widely used by organizations and companies to be used as a reference about the importance of learning in an organization and company. According to Senge (1990) there are five disciplines that play a key role in the success of organizational development and change:

a) system thinking

b) personal mastery

c) mental model

d) building shared vision (building shared vision)

e) team learning

Watkins and Marsick (1993) introduce a learning organization model that is integrated with seven interrelated dimensions at three levels, namely individuals, groups, and organizational levels that are aligned between people and structures. The learning organization model developed by Watkins and Marsick (1993) has several advantages.

Each advantage will be owned by each puskesmas including Kubutambah 1 Public health which is an area with Stunting development slot and Sawan 1 Public health with HIV / AIDS prevention slot area. The advantages of each Public health to become a puskesmas must have a good organization in resolving every problem in each of the target areas. The aim of having an advantage is that the Public health can make a mapping of health problems that must be resolved on a priority scale.

\section{Analyzing the achievements of Puskesmas accreditation performance in Buleleng Regency}

Based on the results of the questionnaire analysis and structured interviews the overall results are shown in table 5.4 that the achievement of accreditation in both puskesmas obtained from the questionnaire analysis Organizational performance for Public health accreditation achievement data seen from the results of Public health accreditation self assessment in Buleleng Regency in 2019 with the number of respondents or The informants are as many as 100 respondents stating that the achievements of accreditation are categorized as good as 98 respondents (98\%) and only a small portion states not as good as 2 respondents (2\%).

Accreditation owned by Kubutambahan Health Center 1 in the Madya category and Public health Sawan 1 in the main category are not easy achievements because what is in that condition is not easy. Based on the theory of Minister of Health Regulation No. 75 of 2014 states that Puskesmas accreditation is an acknowledgment of Public health given by an independent organization conducting accreditation after judging that Puskesmas has met Public health service standards set by the Minister to continuously improve the quality of Public health services. Public health must be accredited periodically at least once every three years to improve service quality.

This Public health accreditation needs to be done because of variations in the quality of Public health administration, which is caused by differences in the process of measuring, monitoring, controlling, maintaining, refining and documenting. Plus there are differences in human resources and infrastructure facilities at the health center that can cause the service process and service quality to be different. The many differences make it necessary to have a standardized process of measuring, monitoring, controlling, maintaining and perfecting documentation. The hope, with everything that is standardized, it will produce a process and quality of good and standardized service quality.

Accreditation performance assessment can be done by doing a self assessment and through a survey by an accreditation surveillance team. Self assessment is carried out by the Public health itself which is then verified by the accreditation assistant team. While the accreditation survey, carried out with the following stages:

a. Process for Submitting Accreditation Assessment

District / City Health Office sends letters of recommendation for accreditation assessment submission to the Provincial Health Office. The letter was then forwarded to the Puskesmas Accreditation 
Commission, then the Puskesmas Accreditation Commission assigned a central and / or provincial survey team to assess the proposed Puskesmas accreditation.

b. Accreditation Survey Process

1) The accreditation survey is carried out for three days.

2) The survey is based on accreditation instrument standards.

3) The survey is conducted by examining existing documents: external and internal documents.

4) Search is done by the method:

a) Interviews, to: Puskesmas leaders, program managers, Puskesmas staff, cross-sectoral, community, patient and patient's family.

b) Observation: implementation of activities, documents as evidence of implementation of activities (recording, reporting).

5) The method of proving documents and traceability, including:

a. Proving that the system is standardized: seen policy documents, quality manuals, internal guidelines, and procedure documents (SOP)

b. Prove the system is running: search for the system.

c. Prove that the system runs according to the procedure: tracking monitoring and proof of monitoring documents.

d. Proving the success of the system: evaluation tracking and evaluation documents.

e. Prove that the system is improved: evidence of problem analysis and corrective efforts (search and documents).

6) Making conclusions on the results of the accreditation assessment that will be reported to the Accreditation Commission for Puskesmas and clinics.

c. How to Assess Accreditation Performance

Evaluation of the performance of Puskesmas accreditation is carried out by means of proof of each element given a value: $0=$ if there is none at all or only a small portion exists $(0 \%-20 \%)$, value $5=$ if most have already been implemented (2079\%) $10=$ if it has been implemented (80-100\%). Achievement number for each element $=$ sum of the scores for each proof. Achievement value of each element $=$ achievement value of each element divided by the number of evidences for each element. Total score for each criterion $=$ total score of all elements in each criterion $\mathrm{x} 100 \%$ divided by the number of elements in each criterion $x 10$. Next to the total score of each chapter $=$ the sum of all elements in each chapter x 100\% divided by the number of elements in each chapter $\mathrm{x} 10$

\section{Analyzing the Effect of Learning Organization on the achievement of Puskesmas accreditation in Buleleng Regency.}

Based on the results of data analysis and conclusions in table 5.5 that there is a close relationship or between the effect of organizational learning on the achievement of Public health accreditation in Buleleng Regency. With a p-value of 0.047 , which means less than $\alpha 0.05$, it is concluded that there is an influence of organizational learning on the achievement of Public health accreditation in Buleleng Regency in 2019. Then proceed with multivariate analysis in research is to find the main factors and other factors that influence organizational influence learning towards achieving the accreditation of Public health in Buleleng Regency in 2019. So the researchers used the Logistic Regression test to determine the relationship of external variables to the achievement of accreditation.

Based on table 5.6 that there is no close relationship between education and informant knowledge on the achievement of Public health accreditation in Buleleng Regency. Where the R-square value of 0.538 means greater than $\alpha 0.05$ so it can be concluded that there is no influence of the education and knowledge of informants or respondents on the achievement of Public health accreditation in Buleleng Regency in 2019.Indeed Organizational performance can be considered as part of the effect of Organizational Learning. Several studies have stated the relationship between Organizational Learning Process or Organizational Learning Capability on organizational performance (for example, Bontis et al., 2002; Tippins \& Sohi, 2003; Lopis Sanchez et al., 2010; Bhatnagar, 2006; Jyothibabu et al, 2010; ).

Knowledge accumulated through Organizational Learning, produces a basis for knowledge at a higher level, which can be associated with high performances at the organizational level (Curado, 
2006; Senge, 1990; Garvin, 1998). The relationship between Organizational Learning and organizational performance is complex, but using a good management system will increase the likelihood of producing better performance. Organizational Learning Capability will affect the Organizational Learning Process. Organizations that have good learning abilities, at the level of individuals, groups and organizations, will be able to do a good learning process as well. A good learning process will provide good results in the organization. Organizational performance can be considered as part of the role of Organizational Learning. It can be concluded that Organizational Learning is very influential on organizational performance because it relates to the selection of the right strategy by aligning the goals and resources owned so that all activities go according to plan, creating stakeholder value, achieving competitive advantage.

The relationship between Learning Organization and Organizational Performance that the Learning Organization concept has been associated with innovation and performance in organizations in several studies (Power \& Waddle, 2004; Watkins and Marsick 1993). The ability to change and carry out continuous improvement efforts to overcome the challenges of the environment, where organizations operate according to the ability of organizations to learn (Foley, 2003; Senge, 1990). Organizations that experience the learning process will be able to equal the development and improvement in the environment (competitors / competitors) in the direction of success. Learning Organizations are needed to survive changes in the rapidly changing external environment. The inability of organizations to learn causes organizations to lose knowledge which will lead to repetitive patterns of mistakes, reduce productivity, and reduce performance. (Martins and Martins, 2011). The results of the correlation test between learning organizations and knowledge performance conducted at the Whiz Hotel in 2015 showed a significant relationship.

Learning Organization has a role as supporting activities in implementing value chain as the main activity in increasing the effectiveness of research and learning conducted by organizations which ultimately brings success to innovation strategies. Research conducted by Nazari (2012) also shows that the Learning Organization dimension is positively and significantly correlated with the scale of organizational commitment.

\section{Suggesting efforts to improve the performance of Puskesmas accreditation in Buleleng Regency using the Organizational Learning theory approach}

After reviewing, there are several obstacles that have caused the implementation of organizational learning in these two puskesmas, including: The large number of patients visiting the Public health causes the Public health head to perform functional tasks. Organizational learning is not familiar to the Public health staff. It is more difficult to be a leader than to be led, especially those who are led far from the head of the Public health. Public health staff carry out outdoor service activities which result in difficulty gathering friends.

To improve the performance of Public health accreditation in Buleleng Regency with the Organizational Learning theory approach. Organizational Learning can be measured in two factors, Organizational Learning Capability and Organizational Learning Process. Organizational Learning Capability is a managerial and organizational (organizational factor) factor that facilitates the organizational learning process or allows an organization to learn (Dibella et al., 1996), so the Public health need to make a satisfaction survey regarding the ability of the Public health head to lead. In addition, the service satisfaction survey is filled out by the community so that they know the extent of the services provided at the Public health. The Public health also made SWOAT evaluation and analysis reports on managerials from the Public health Sawan 1 and Public health Kubutambahan 1.

\section{CONCLUSION}

Based on the results of research that has been done, the following conclusions can be drawn:

1. The results of the analysis of the Learning Organization Public health in Buleleng Regency show that out of 100 respondents or informants from 2 Public health namely Kubutambah 1 and Sawan 1 there were Learning Organizations in the good category of $62 \%$ and not good as much as $38 \%$

2. The results of the analysis of the achievement of the performance of accreditation at the Public health in Buleleng Regency showed that out of 100 respondents or informants from 2 Public health 
namely Kubutambah 1 and Sawan 1 there were Learning Organizations in the good category of $98 \%$ and not good as much as $2 \%$

3. The results of the analysis of the relationship between Learning Organization and the performance of Puskesmas accreditation in Buleleng with chi square statistical tests and logistic regression that there is a close relationship or between the influence of organizational learning on achieving Public health accreditation in Buleleng Regency. With a p-value of 0.047, which means less than $\alpha 0.05$, it is concluded that there is an influence of organizational learning on the achievement of Public health accreditation in Buleleng Regency in 2019. Then proceed with multivariate analysis in research is to find the main factors and other factors that influence organizational influence learning towards achieving the accreditation of Public health in Buleleng Regency in 2019. So the researchers used the Logistic Regression test to determine the relationship of external variables to the achievement of accreditation. Where the R-square value of 0.538 means greater than $\alpha 0.05$ so it can be concluded that there is no influence of the education and knowledge of informants or respondents on the achievement ofPublic health accreditation in Buleleng Regency in 2019.

4. Efforts to improve the achievement of accreditation are largely determined by the readiness of the head of the Public health to run the program.

\section{DAFTAR PUSTAKA}

Aghaei, N., Ziaee, A. \& Shahrbanian, S., 2012. Relationship between learning organization and organizational commitment among employees of Sport and Youth head Office of western provinces of iran. European Journal of Sports and Exercise Science, Volume 1(3), p. $59=69$.

Alegre, J. \& Chiva, R., 2009. Entrepreneurial orientation, organizational learning capability and performnace in the ceramc tle industry. WP-EC, Volume 08, pp. L26-L61.

Argyris, C., \& D. Schoen 1978 Organizational learning: A theory of action perspective.Reading, MA: Addison-Wesley Publishing Co.

Atak, M. \& Erturgut, R., 2010. An empirical analysis on the relation between learning organization and organizational commitment. Procedia Social and Behavioral Sciences, Volume 2, pp. 3472-3476.

Azwar, A. \& Prihatono, J., 2003. Metodologi Penelitian Kedokteran dan Kesehatan Masyarakat. Jakarta: Binarupa Aksara.

Blackler, F., M. Reed, \& Whitaker, A., 1993 'Editorial introduction: Knowledge workers and contemporary organizations'. Journal of Management Studies,30(6), 851-861.

Bierly, P., \& Chakrabarti, A., 1996 'Generic knowledge strategies in the US pharmaceutical industry'. Strategic Management Journal, 17(Winter Special Issue), 123-135.

Brown, J. S., \& Duguid, P., 1991 'Organizational learning and communities of practice: toward a unified view of working, learning, and innovation'. Organizational Science, 2, 40-57.

Chajnacki, G. M. 2007. Characteristics of Learning Organizations and Multi- Dimensional Orgaizational Performance Indicators: a Survey of Large. Publicly-Owned Companies. Thesis. The Pennsylvania State University. UMI Number: 3266083.

Chiva, R. \& Joaquin, A., 2014. Measuring Organizational Learning Capability Among The Workplace. International Journal of Menpower, Volume 28 No 3/4, pp 224-242.

Cinar, F. \& Eren, E., 2015. Organizational Learning Capacity Impact on Sustainable Innovation : the Case Of Public Hospitals. Procedia - Social and Behavioral Sciences, Volume 181, pp. 251-260.

Çömleka, O., Kitapçı, H., Çelikc, V., 2012. "The Effects of Organizational Learning Capacity on Firm Innovative Performance". Procedia - Social and Behavioral Sciences 41 ( 2012 ) $367-374$

Crossan, M., Lane, H., \& White, R., 1999. 'An organizational learning framework: From intuition to institution'. Academy of Management Review, 24(3), 522-538.

Dibella A.J., Nevis E.C., Gould J.M., 1996. Understanding organizational learning capability. J. Manage. Stud., 33(3): 361-379. 
Donnelly, J. H., Gibson, J. L. \& Ivancevich, J., 1996. Manajemen Edisi Sembilan. Jakarta: Erlangga.

Dixon, 1994. The Organizational Learning Supervisi Cycle, McGraw-Hill: Maindenhead Finger, M and Brand, S.B., 1999. The Concept of The "Learning Organization" Applied to The Transformation of The Public Sector in M. Easterby-Smith, L. Araujo and J. Burgoyne (Eds) Organizational Learning and The Learning Organization, London; Sage. https//www.infed.org/biblio/learning-organization.htm

Gibson, J., 1996. Organisasi, Perilaku, Struktur, Proses, Jilid 2. Jakarta: ErlanggaGoh, Swee, 1997. Benchmarking The Learning Capability of Organization. European Management Journal. Volume 15 No 5, pp 575-583.

Hanaysha, J., 2016. TestingtheEffects of Employee Engagement, Work Environment, and Organizational Learning on Organizational Commitment. Procedia Social and Behavioral Sciences, Volume 229, pp. 289-297.

Hedberg, B., 1981. 'How organizations learn and unlearn'. In P. C. Nystrom and W. H. Starbuck (Eds.), Handbook of Organizational Design: 3-27. Oxford, England: Oxford University Press.

Henry Mitzberg, 1998. Strategy Safari, A Guided Tour Through The Wilds of Strategic Management (New York, London, The Free Press);

Huber, .P., 1991. "Organizational Learning: The Contributing Processes and The Literatures", Organizational Science.Vol. 2 (February), pp.88 115

Hussein, N., Mohamad, A., Noordin, F. \& Ishak, N. A., 2014. Learning Organization and its Effect on Organizational Performance and Organizational Innovativeness: a proposed Framework for Malaysian Public Insttitutions of Higher Education. Procedia, Social and Behavioral Sciences, Volume 130, pp. 299-304.

Ilyas, Y., 2012. Kinerja : teori, penilaian dan penelitian. Depok: Fakultas Kesehatan Masyarakat Universitas Indonesia.

Issacs, R. H., 1993. "Basic Group Identity: The Idol of the Tribe". Cambridge: Harvard University Press.

Ivancevich, J. M., Konopaske, R. \& Mattenson, M. T., 2006. Perilaku dan Manajemen Organisasi. 7 ed. s.l.:Erlangga.

Je'rez-Go' mez P, Cespedes-Lorente J, Valle-Cabrera R., 2005. Organizational learning and compensation strategies: evidence from the Spanish chemical industry. Hum. Resour. Manage., 44 (3): 279-299.

Jiménez-Jiménez, D., dan Sanz-Valle, R., 2011. Innovation, organizational learning, and performance. Journal of Business Research, 64(4), 408-417.

Kanten, P., Kanten, S. \& Gurlek, M., 2015. The Effects of Organizational Structures and Learning Organization on Job Embeddedness and Individual Adaptive Performances. Procedia Economics and Finance, Volume 23, pp.1358-1366.

Kopelman, R. E., 1986. Managing Productivity in Organization: a Practical People Oriented Perspective. New York: Mc Graw-Hill.

Kumar, J. K., Gupta, R., Basavaraj, P. \& Singla, A., 2016 Jun. An Insight into Healthcare Setup in National Capital Region of India using Dimensions of Learning Organizations Questionnaire $(\mathrm{DLOQ})=\mathrm{A}$ Cross-Sectional Study. Journal of Clinical and Diagnostic Research, Volume 10(6), pp. ZC01- ZC05.

Leavitt, C. C., 2011. A Comparative Analysis of Three Unique Theories of Organizational Learning. 1131 Mesa Vista Drive

Leavit, J.R., 1986. Psikology Management : Sebuah Pengantar Bagi Individu dan Kelompok di Dalam. (Terjemahan: Zakarsi, M. Ed.4). Jakarta. Erlangga

Luciana, A., 2013. Organizational Learning and Performance, a Conceptual Model. Bucharest, s.n.

Luthans, F. 1995. Organizational Behaviour. Tokyo: McGraw-Hill Kogakhusa. Ltd

Maktabi, S. H. \& Khazaei, A. 2014. The Impact of Organizational Learning on Organizational Performance : Evidence from Bank Industry of Iran. International Journal of Economy, 
Management and Social Sciences and Organizational Innovation. Vol(3), No (10), October, 2014. pp. 569-573

Marsick, V. J. \& Watkins, K. E., 2003. Demonstrating the Value of an Organization,s Learning Culture: The Dimensions of the Learning Organization Questionnaire. Advances in Developing Human Resources, Volume 5, pp. 132-151.

Marquardt, Michael .J., 2002. Building The Learning Organization : Mastering The 5 Elements for Corporate Learning. Palo Alto: Davies Black Publishing Inc.

Nazari, K. \& Pihie, Z. A. L., 2012. Assessing Learning organization Dimensions and Demographic Factors in Technical and Vocational Colleges in Iran. International Journal of Business and Social Science, Volume 3, pp. 210-219.

Nevis, E., DiBella, A., \& J. Gould. 1995. 'Understanding organizations as learning systems'. Sloan Management Review, Winter, 73-85.

Njuguna, John, I., 2009. "Strategic Positioning For Sustainable Competitive Advantages: An Organizational Learning Approach". Kca Journal of Businness Management : Vol. 2. Issue 1

Nonaka, I \& Takeuchi, H. 1995. The Knowledge Creating Company : How japanese Companies Create The Dynamics of Innovations. New York: Oxford University Press

Notoatmojo, S., 2010. Metodologi Penelitian Kesehatan. Jakarta: Rineka Cipta. Ortenblad, A., 2001. On Differences Between Organizational Learning and Learning Organization, The Learning Organization. Vol. 8, No.3

Pedler M, Burgoyne J, Boydell T., 1997. The Learning Company: a Strategy for Sustainable Development. McGraw-Hill, Maidenhead.

Prange, C, 1999. Organizational learning - desperately seeking theory?', In "Organizational Learning and the Learning Organisation. Sage, London, pp.23-43.

Riyanto, A., 2009. Aplikasi Metodologi Penelitian Kesehatan. Yogyakarta: Nuha Medika.

Saadat, V. \& Saadat, Z., 2016. Organiational Learning as a key role on organizational success. Procedia, 230 (Organizational Learning), pp. 219-225.

Schendel, D., 1996 'Knowledge and the firm'. Strategic Management Journal, 17(Winter Special Issue), 1-4.

Scott-Ladd BC, Chan CA., 2004. Emotional intelligence and participation in decision-making: strategies for promoting organizational learning and change. Strat. Change., 13, pp. 95105.

Senge, P.M., 1990. The Fifth Discipline: The Art and Practice of the Learning Organization. New York: Currency Doubleday.

Sinkula, J.M., 1994. Market Information Processing and Organizational Learning, Journal of Marketing, Vol.58, No.1, pp.35-45.

Sitkin SB (1996). Learning through failure. In: Cohen, M., Sproull, L. (Eds.), Organizational Learning. Sage Publications, California.

Song, J. H., Joo, B.-K. \& Chermack, T. J., 2009. The Dimensions of Learning Organization Questionnaire (DLOQ):a validation Study in a Korean Context. Human ResourceD evelopment Quarterly, Volume 20, pp. 43-60.

Spender, J., 1994 'Knowing, managing, and learning'. Management Learning, 25(3), pp. 387412.

Spender, J., \& R. Grant. 1996 'Knowledge and the firm: overview'. Strategic Management Journal, 17(Winter Special Issue), 5-9.

Spender, J. C., 1996 'Making knowledge the basis of a dynamic theory of the firm'. Strategic Management Journal, 17(Winter Special Issue).

Supriyanto, S. \& Djohan, A., 2011. Metodologi Riset Bisnis dan Kesehatan. Banjarmasin: PT Grafika Wangi Kalimantan.

Tannenbaum S., 1997. Enhancing Continuous Learning: Diagnostic Findings from Multiple Companies. Hum. Resour. Manage. 36, pp. 437-452.

Thomas L. Wheelen, Hunger, J.D., 2002. Strategic Management and Business Policy. Eight edition. Upper Saddle River New Jearsey. Prentice Hall 
Tsang, E.W.K., 1997. Organizational Learning and Learning Organization: A Dichotomy Between Descriptive and Prescriptive Research, HR

Ulrich D, Jick T, Von Glinow MA., 1993. High-impact learning: building and diffusing learning capability. Organ. Dynam., 22 (2), pp. 52-79

Watkins, K. E. \& Marsick, V. J., 1993. Sculpting the Learning Organization: Lessons in the Art and Science of Systemic Change. San Francisco: Jossey- Bass

Weick, K.E, Westley, F., 1996. Organizational learning: affirming an oxymoron.In SR Clegg, C Hardy, W R Nord (eds), Handbook of Organizational Studies, London: Sage. 440- 458.

Widi, L., 2011. "Pengaruh Upah, Tingkat Pendidikan dan Teknologi Terhadap Produktivitas

Tenaga Kerja Pada Industri Kecap di Kecamatan Pati Kabupaten Pati”. Skripsi. Jurusan Ekonomi Pembangunan, Universitas Negeri Semarang.

Wong, P. S. \& Cheung, S. O., 2008. An analysisi of the relationship between learning behaviour and performance improvement of contracting organizations. International Journal of Project Management, Volume 26, p.112=123.

Yanuardi, R., 2013. Pengaruh Keterampilan Kerja dan Pengetahuan Administrasi terhadap Kinerja Pegawai Administrasi Fakultas Ekonomi Universitas Negeri Padang. Dalam https://www.google.co.id/url?sa=t\&rct=j\&q=\&esrc=s\&source=web\&cd=6\&

Yeung A.K., Ulrich DO, Nason S.W., Von Glinow, M., 1999. Organizational Learning Capability. Oxford University Press, New York

Youzbashi, A. \& Mohammadi, A., 2013. an Investigation into the realization dimension of learning organization. Procedia Social and Behavioural Sciences, Volume 47, pp. 90-92.

Zgrzywa, A., The Impact of Organizational Learning on Organisational Performance. Journal of Management and Business Administration. Central Europe" Vol. 23, No. 4/2015: p. $98-112$ 